\title{
A word of caution when planning forest management using projections of tree species range shifts
}

\author{
by Yueh-Hsin Lo ${ }^{1,2}$, Juan A. Blanco ${ }^{1,3}$ and J.P. (Hamish) Kimmins ${ }^{1}$
}

\begin{abstract}
In this note we raise our concerns about the use of climate envelope models as a basis for forest planning under climate change. Such models assume constant relationships among tree species presence, abundance or growth rates and climatic variables, and that these can be transferred from their current distribution areas to areas that are predicted to have a similar future climate. Climate is an important determinant of tree species distributions, but its effects are mediated through soils, competition from other plant species, herbivores, diseases, insects and fire. This complexity should be addressed when making predictions about plant species distribution changes. If forecasts based only on climate are accepted uncritically and become the basis for forest policy and practice, there could be important consequences for the success of forest management. We illustrate the issue with the historical response of tree growth to climate variability for three conifer species along an altitudinal gradient in southern interior British Columbia. The growth-climate relationships differ not only among species but also between ecological zones, which implies that the different combinations of tree species and site will react differently to the same change in climate. All things considered, caution is needed when developing management plans using predicted future tree distributions based only on current/past tree/climate relationships.
\end{abstract}

Key words: climate-envelope models, climate change, species distributions, dendroclimatology

\section{RÉSUMÉ}

Nous voulons souligner par cet article notre inquiétude relativement à l'utilisation des modèles de couverture climatique en tant que référence pour la planification forestière dans un contexte de changements climatiques. Ces modèles assument des relations constantes associées à la présence despèces d’arbres, à l'abondance ou à des taux de croissance et à des variables climatiques et quelles peuvent être transférées de leurs zones actuelles de distribution à des zones pour lesquelles on prévoit un climat semblable dans l'avenir. Le climat est un facteur déterminant de la distribution des espèces, mais ses effets sont modifiés par le sol, la compétition exercée par d'autres espèces de plantes, les herbivores, les maladies, les insectes et le feu. Cet aspect complexe devrait être considéré lorsque des prédictions sont faites relativement aux changements dans la distribution des espèces de plantes. Dans le cas où des prévisions reposant seulement sur le climat sont acceptées sans aucun questionnement et deviennent la référence pour des politiques et des pratiques forestières, cela pourrait générer d'importantes conséquences sur la réussite de l’aménagement forestier. Nous illustrons cet aspect au moyen de la réaction habituelle de la croissance des arbres face à des variations climatiques pour trois espèces de conifères réparties à la même altitude dans le sud-intérieur de la Colombie-Britannique. Les relations entre la croissance et le climat sont différentes non seulement entre les espèces mais également entre les zones écologiques, ce qui implique que des combinaisons différentes d’espèces d’arbres et de stations réagiront différemment face à la même modification du climat. Toutes choses étant considérées, il faut agir avec prudence lors de lélaboration de plans d’aménagement impliquant des simulations de distributions futures d'espèces d’arbres reposant seulement sur les relations actuelles et antérieures entre les arbres et le climat.

Mots clés : modèles de couverture climatique, changements climatiques, distributions des espèces, dendroclimatologie

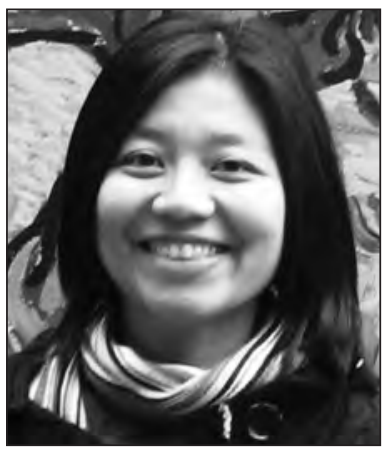

Yueh-Hsin Lo

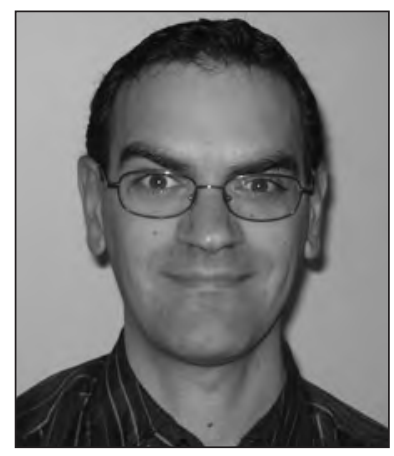

Juan A. Blanco

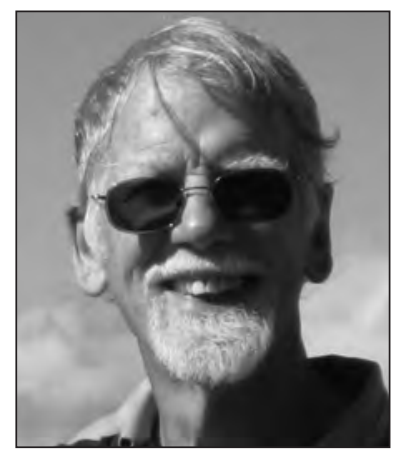

J.P. (Hamish) Kimmins

\footnotetext{
${ }^{1}$ University of British Columbia, Faculty of Forestry, Dep. Forest Sciences, 2424 Main Mall, Vancouver, British Columbia V6T1Z4.

${ }^{2}$ Present address: School of Forestry and Resource Conservation, National Taiwan University, No. 1, Sec. 4, Roosevelt Road, Taipei, 10617, Taiwan (R.O.C.).

${ }^{3}$ Corresponding author. E-mail: juan.blanco@ubc.ca
} 


\section{Introduction}

Climate change is a global phenomenon that is already altering tree species ranges. Tree lines shifting upwards and polewards have been reported in Europe, Asia and America (Dullinger et al. 2004, Soja et al. 2007, Harsch et al. 2009), but recent research has failed to identify direct links between warmer temperatures and observed changes in species ranges (MacDonald et al. 1998, Dullinger et al. 2004, Wilmking et al. 2004). The important ecological, economic and social consequences of such changes have prompted multiple modelling efforts to predict the future locations of distribution ranges and habitats within these ranges that will be suitable for particular tree species.

Defining such areas has consequences for forest management and conservation. For example, assisted colonization (planting trees in areas outside of their current ranges but within predicted future climatically suitable areas) is already being discussed as a way to preserve endangered species (McLachlan et al. 2007, Millar et al. 2007) or to maintain future forest productivity (Marris 2009). The first steps towards implementation of this strategy are already underway in British Columbia (western Canada) where concerns about changing tree habitat suitability under climate change are leading the forestry community to ask for more action and policy guidance (J. Snetsinger, B.C. Chief Forester; as cited in Marris 2009).

The most popular approaches to the prediction of future areas of suitable habitat for commercial tree species involve analysis of historical records of tree lines in boreal and alpine environments (Dullinger et al. 2004), using climate envelope models (Hamann and Wang 2006), or using dendroclimatology to link climate and tree growth rates (Wilmking et al. 2004). Based on these methods, combined with other information such as soil or topography, maps of potential future habitat suitability have been generated (e.g., Iverson et al. 2008). Such predictions are useful in assessing relationships between current climate and tree distribution, abundance and growth, and may under some conditions be helpful as a starting point for planning forest management at broad scales under changing climate. Shortcomings of these approaches have been discussed in the literature (Pearson and Dawson 2003, Thuiller et al. 2008), but it appears that awareness of these shortcomings has not yet developed within the forest management community.

The objective of this note is to raise awareness and foster debate among managers and other stakeholders about the current limitations of modelling future tree ranges, and the risks of accepting predictions of models that do not account for all the major determinants of future forest composition. We illustrate our concerns with the results of a dendroclimatological study of historical tree growth-climate relationships for three species along an altitudinally induced ecological gradient in the southern interior of British Columbia, Canada.

\section{Shortcomings of Tree Range Shift Predictions Based Mostly on Climate}

Current dominant tree cover, the composition of which reflects many ecological determinants including climate, has persisted through periods of significant climatic change, especially in forests with long-lived trees. Growth and habitat distributions of herb and shrub species often respond more to local changes in soil moisture and nutritional gradients, the determinants of which include many non-climatic variables. Therefore, it is unlikely that changes in climate variables of the scale of predicted climate change $\left(+2^{\circ}\right.$ to $4^{\circ} \mathrm{C}$ and $\pm 5 \%$ to $20 \%$ precipitation in the next century; IPCC 2007) will be sufficient to produce a shift in species ranges on their own. Additional non-climatic factors such as competition, seed production, invasibility and migration rates will be equally or more important (Davis et al. 1998, Grace et al. 2002, Dullinger et al. 2004), as well as factors only indirectly related to climate such as rate, type and intensity of disturbances (Bergeron et al. 2004).

If the ecological effects of these other determinants are well correlated with climate, climate envelope models may prove useful for general planning at broad regional scales. However, at landscape and stand scales (the most meaningful for forest planning), topography, geology, slope, aspect and soils will, among other ecosystem characteristics, modify the direct effects of regional climate on trees (Pearson and Dawson 2003). Because the shortcomings of climate envelope models have been reviewed before (Pearson and Dawson 2003, Heikkinen et al. 2006, Dormann 2007), we only mention the basic points here.

Previous studies have advanced maps of future suitable habitat for commercial tree species for projected future climates (Hamann and Wang 2006, Iverson et al. 2008). Such models are based on the assumption that present-day tree distributions are in an equilibrium state determined by the interaction of climate with topographic and edaphic conditions. However, an equilibrium hypothesis is by definition unsuitable as a predictor of dynamic responses of vegetation to climate change (Woodward and Beerling 1997). This issue increases in importance when moving from continental and large regional scales, where climate can be the main driver of current tree abundance and distribution, to landscape scales where local factors can be as or more important than climate (Pearson and Dawson 2003). Without accounting for non-climatic factors, climate envelope models lack practical utility to support management decisions (Davis et al. 1998, Grace et al. 2002, Thuiller et al. 2008).

Evidence from field studies shows that observed shifts in tree ranges are not always linked to changes in climate. For example, Harsch et al. (2009) reviewed reported treeline movements, but displacement accompanying warmer temperatures was detected in only $50 \%$ of the cases, mostly because of the importance of non-climatic local factors. Bergeron et al. (2004) showed that the limit between mixed-wood and coniferous forest in northeastern North America, which apparently matches climatic boundaries, is actually the result of wildfires. Although fire risk and severity are related to climate, there are other factors to be considered. Consequently, climatic correlations with present species distributions are also not necessarily a valid proxy for possible future tree distributions. In addition, many forests, especially in the northern hemisphere, have not yet reached equilibrium after the last glaciation and do not yet fully occupy their current potential habitats (Bergeron et al. 2004, Svenning and Skov 2004).

Responses to changing climate are species-specific, and might vary between local populations and provenances of the same species due to within-population genetic diversity (Hurtley 1991, Wilmking et al. 2004). When climate changes, 
overall fitness of some species may be reduced initially, but after a number of generations, selection from the different genotypes within the population may lead to recovery of the fitness and biomass exhibited before the onset of climate change (Davis et al. 2005). The idea of speeding up this selection is behind the current assisted migration adaptation trials started in B.C. (Marris 2009), but it remains unclear whether these trials will produce useful results in a time frame suitable for current planning decisions.

As climate changes, climatic zones may cross geological and soils boundaries, changing the relationships between climate and trees. Different species will migrate at different speeds, but many current tree populations will remain in their present ranges, making it difficult for southern and lowland species to successfully establish themselves, unless the present populations are eliminated via disturbances. In addition, many species can grow well in environments warmer than their current ranges, but are prevented from doing so through mechanisms of competition with faster-growing species, not because of poor adaption to climate (Hurtley 1991). As a result, new biological communities will be created in a process similar to post-glaciation colonization, which in some areas is still underway. Therefore, planning future forest management under the wrong assumption that current ecosystems will simply be displaced northwards or upwards seems to be risky. Specific ecosystems will not move, since the geo-physical components of the ecosystem are a relatively permanent site feature. If biotic communities do move, they will encounter different topographic, geological and edaphic conditions, creating new physical/biotic combinations-new ecosystems. Whether these new combinations are functionally viable ecosystems under the new climate remains to be seen.

In the biogeoclimatic classification of British Columbia (the legally required basis for current forest management planning in the province), ecological zones are broadly defined by macroclimate and the range of dominant, late-successional species on zonal sites (Pojar et al. 1987). However, the actual plant communities within this climatic framework are strongly modified by topographically induced local gradients of moisture and nutrients, fire, and the action of herbivores, insects and diseases. As one moves from cooler, wetter existing zones to warmer, drier zones, the mosaic of vegetative communities simply shift along local, edaphically and topographically induced soil moisture and fertility gradients, with relatively modest changes in the overall species composition of the zone (Kimmins 1987 and Stathers et al. 1990). This is especially true in areas with strong topography and steep soil gradients. It is less true in areas of rolling plateaus with subdued topography. As a consequence, climate envelope models could misguide managers unless accompanied by a consideration of other ecosystem components and processes that are known to modify the effects of climate on plants.

\section{An Example of Different Tree Responses to Histori- cal Climate Variability}

In order to explore the extent to which climate can be regarded as responsible for changes in tree growth, we conducted a dendroclimatological study in the southern interior of B.C. A detailed description of the sites and the dendrochronological and statistical methods is provided in Lo (2009) and Lo et al. (2010). In summary, we sampled 300 trees to characterize the regional tree population-level response to climate by taking increment cores from lodgepole pine (Pinus contorta Dougl.), Douglas-fir (Pseudotsuga menziesii [Mirb.] Franco), and hybrid spruce (Picea glauca $\mathrm{x}$ engelmannii) from zonal sites in each of three ecological zones along an altitudinal gradient (IDF: Interior Douglas-fir 1100-1350 m.a.s.l., MS: Montane Spruce 1350-1500 m.a.s.l., ESSF: Engelmann Spruce-Subalpine Fir 1500-1800 m.a.s.l.; Pojar et al. 1987). We followed standard dendroclimatological practices to remove non-climatic signals and to create a common residual chronology for every species in each ecological zone (Lo et al. 2010). These residual chronologies were correlated and regressed (first individually in linear regressions, then the significant variables together in a forward stepwise multiple regression) with climate variables derived from the Environment Canada weather station in Westwold for the period 1922 to 1997 and extended to each BEC zone in the area using the MTCLIM model (Thornton et al. 1997).

Our results showed that the strongest historical relationships between individual climate variables and radial growth varied among species and zones (Table 1). Lodgepole pine showed the most significant correlation with temperatures in the lowest zone, but the relationship changed to winter precipitation and potential evapotranspiration (PET) with increasing elevation. Growing season precipitation was the most significant variable for Douglas-fir in the low-elevation zone, but the Pacific decadal oscillation (PDO) dominated in the mid-elevation zone. Summer precipitation was the most significant variable for hybrid spruce in the mid-elevation zone, but was replaced by the climate moisture index (CMI) in the highest zone. Although all these relationships were highly significant, they only explained $20 \%$ of radial growth variability at most (Table 1). Multivariate models explained more variability, up to $53 \%$ (Table 1), but again different variables were chosen for each combination of tree species and ecological zone. For Douglas-fir and hybrid spruce, models changed from precipitation-related variables to temperaturerelated variables when increasing altitude, but the same was not true for lodgepole pine.

As our results indicate, changes in climate have changed tree growth rates and this will continue in the future, but they also show that climate only explains a portion of radial growth variability, which can go from important to modest depending on the species and site (Table 1). Our populationlevel study is more representative of the influence of climate at landscape scales than classical dendrochronological studies that focus on trees growing on sites with extreme temperature/moisture conditions, where climate can be the most limiting factor (Wilmking et al. 2004). However, even for those trees, climate rarely explains more than $60 \%$ of growth rate variability, which suggests that spatial and temporal variability in non-climatic and local factors can be as important as variations in regional climate (Lo 2009, Lo et al. 2010). Our results also suggest that migration of current tree species communities in these sites northwards or upwards as whole ecological units is unlikely because of site- and species-specific response to different climatic and non-climatic features. What could favour expansion for one species (i.e., increased summer precipitation in the MS zone for lodgepole pine) could also benefit other species (e.g. hybrid spruce) but be irrelevant for another species in the same community (i.e., 
Table 1. Climate variables with the strongest relationship with radial growth for each tree species and BEC zone. Subindices (-1) indicate previous year. Winter: December, January, and February. Growing season: May, June, July, and August. Cp: Mallow's Cp coefficient. See Lo (2009) and Lo et al. (2010) for a complete description and discussion of these results.

\section{Univariate model}

\begin{tabular}{|c|c|c|c|c|c|c|c|c|c|}
\hline \multirow[b]{2}{*}{ Tree species } & \multirow{2}{*}{$\begin{array}{l}\text { BEC } \\
\text { zone }\end{array}$} & \multirow[t]{2}{*}{ Variable } & \multicolumn{3}{|c|}{ Coefficients } & \multirow[t]{2}{*}{ Variables } & \multicolumn{3}{|c|}{ Coefficients } \\
\hline & & & $\mathbf{r}$ & $\mathbf{r}^{2}$ & $\mathbf{p}$ & & & $\mathbf{r}^{2}$ & $\mathrm{Cp}$ \\
\hline \multirow[t]{6}{*}{ Lodgepole pine } & IDF & $\mathrm{T}_{\text {mean annual minimum }}$ & 0.415 & 0.172 & $<0.001$ & $\mathrm{~T}_{\text {mean annual minimum }}$ & $\mathrm{P}_{\text {February }}$ & 0.273 & 1.001 \\
\hline & MS & $\mathrm{P}_{\text {August-1 }}$ & 0.394 & 0.155 & 0.002 & $\mathrm{PET}_{\text {May }}$ & $\mathrm{P}_{\text {Winter }<300 \mathrm{~mm}^{\mathrm{a}}}$ & & \\
\hline & & & & & & $\mathrm{PDO}_{\text {January }}$ & $\mathrm{T}_{\text {November-1 }}$ & 0.531 & 5.423 \\
\hline & ESSF & $\mathrm{PET}_{\text {May }}$ & -0.395 & 0.156 & $<0.001$ & $\mathrm{PDO}_{\text {April }}$ & $\mathrm{P}_{\text {August-1 }}$ & & \\
\hline & & & & & & $\mathrm{P}_{\text {October-1 }}$ & $\mathrm{T}_{\text {May-1 }}$ & & \\
\hline & & & & & & $\mathrm{P}_{\text {Winter }}$ & $\mathrm{PET}_{\text {February }}$ & 0.391 & 4.791 \\
\hline
\end{tabular}

Douglas-fir IDF $\quad \mathrm{P}_{\text {growing season }<200 \mathrm{~mm}^{\mathrm{a}}}$

\begin{tabular}{|c|c|c|c|c|c|c|c|c|c|}
\hline & \multirow{4}{*}{ MS } & \multirow{4}{*}{$\mathrm{T}_{\text {May-1 }}$} & \multirow[t]{2}{*}{0.439} & \multirow[t]{2}{*}{0.193} & 0.001 & $\mathrm{P}_{\text {May }}$ & \multicolumn{3}{|l|}{$\mathrm{T}_{\text {July-1 }}$} \\
\hline & & & & & & $\mathrm{PET}_{\text {July }}$ & $\mathrm{P}_{\text {annual }}$ & 0.432 & -1.205 \\
\hline & & & 0.375 & 0.141 & 0.004 & $\mathrm{~T}_{\text {May-1 }}$ & $\mathrm{T}_{\text {January }}$ & & \\
\hline & & & & & & $\mathrm{T}_{\text {November- } 1}$ & $\mathrm{P}_{\text {Winter }<300 \mathrm{~mm}^{\mathrm{a}}}$ & 0.416 & 4.091 \\
\hline \multirow[t]{3}{*}{ Hybrid spruce } & MS & $\mathrm{P}_{\text {summer }}$ & 0.278 & 0.077 & 0.025 & $\mathrm{P}_{\text {July-1 }}$ & $\mathrm{P}_{\text {August-1 }}$ & 0.112 & 2.652 \\
\hline & ESSF & $\mathrm{T}_{\text {August- } 1}$ & -0.381 & 0.145 & 0.003 & $\mathrm{~T}_{\text {August-1 }}$ & $\mathrm{T}_{\text {July-1 }}$ & & \\
\hline & & & & & & $\mathrm{T}_{\text {June }}$ & & 0.324 & 6.352 \\
\hline
\end{tabular}

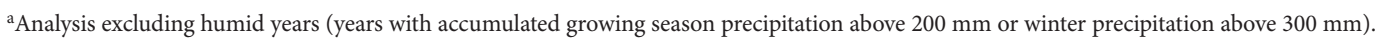

Douglas-fir). Therefore, future plant communities in the area will be different from current and historical communities in distribution, abundance and growth rate of plant species. This should be taken into account in forest management plans, but it is generally not captured by climate-envelope models designed for large regional scales.

\section{Conclusions}

We conclude that predicted shifts in climatic zones are not a suitable proxy, on their own, for predicting shifts in species ranges at the landscape level. Borders between current plant communities are often decided by the incidence and severity of disturbances, which will likely change under future climatic conditions but will not be directly related to changes in temperature and precipitation. Predicting geographical changes in soils, trees, lesser vegetation and wildlife at scales meaningful for forest management involves greater complexity than is included in climatic envelope models. Therefore, we advocate the use of more complex, process-based models that incorporate a greater proportion of the key determinants of possible forest futures to deal adequately with the increasing uncertainty of future tree growth and climate change effects on forests (Kimmins et al. 2008).

\section{Acknowledgements}

The authors would like to thank Dr. B.T. Guan (National Taiwan University) for his financial support.

\section{References}

Bergeron, Y., S. Gauthier, M. Flannigan and V. Kafka. 2004. Fire regimes at the transition between mixedwood and Coniferous boreal forest in northwestern Quebec. Ecology 85: 1916-1932.

Davis, A.J., L.S. Jenkinson, J.H. Lawton, B. Shorrocks and S. Wood.1998. Making mistakes when predicting shifts in species range in response to global warming. Nature 391: 783-786.

Davis, M.B., R.G. Shaw and J.R. Etterson. 2005. Evolutionary responses to changing climate. Ecology 86: 1704-1714.

Dormann, C.F. 2007. Promising the future? Global change projections of species distributions. Basic Appl. Ecol. 8: 387-397.

Dullinger, S., T. Dirnböck and G. Grabherr. 2004. Modelling climate change-driven treeline shifts: relative effects of temperature increase, dispersal and invasibility. J. Ecol. 92: 241-252.

Grace, J., F. Berninger and L. Nagy. 2002. Impacts of climate change on tree line. Ann. Bot. 90: 537-544.

Hamann, A. and T. Wang. 2006. Potential effects of climate change on ecosystem and tree species distribution in British Columbia. Ecology 87: 2773-2786.

Harsch, M.A., P.E. Hulme, M.S. McGlone and R.P. Duncan. 2009. Are treelines advancing? A global meta-analysis of treeline response to climate warming. Ecol. Lett. 12: 1040-1049. 
Hurtley, B. 1991. How plants respond to climate change: migration rates, individualism and the consequences for plant communities. Ann. Bot. 67: 15-22.

Heikkinen, R.K., M. Luoto, M.B. Araújo, R. Virkkala, W. Thuiller and M.T. Sykes. 2006. Methods and uncertainties in bioclimatic envelope modelling under climate change. Prog. Phys. Geog. 30: 751-777.

IPCC. 2007. Climate Change 2007: The Physical Science Basis. Contribution of Working Group I to the Fourth Assessment Report of the Intergovernmental Panel on Climate Change. Cambridge University Press, Cambridge, UK. 996 p.

Iverson, L.R., A.M. Prasad, S.N. Matthews and M. Peters. 2008. Estimating potential habitat for 134 eastern US tree species under six climate scenarios. For. Ecol. Manage. 254: 390-406.

Kimmins, J.P. 1987. Forest ecology. MacMillian Publishing Company, New York. 531 p.

Kimmins, J.P., J.A. Blanco, B. Seely and C. Welham. 2008. Complexity in Modeling Forest Ecosystems; How Much is Enough? For. Ecol. Manage. 256: 1646-1658.

Lo, Y.-H. 2009. Relationships between climate and annual radial growth in three coniferous species in interior British Columbia, Canada. PhD thesis. University of British Columbia.

Lo, Y.-H., J.A. Blanco, B. Seely, C. Welham and J.P. Kimmins. 2010. Relationships between Climate and Tree Radial Growth in Interior British Columbia, Canada. For. Ecol. Manage. 259: 932-942. Marris, E. 2009. Forestry: Planting the forest of the future. Nature 459: 906-908.

MacDonald, G.M., J.M. Szeicz, J. Claricoates and K.A. Dale. 1998. Response of the central Canadian treeline to recent climatic changes. Ann. Assoc. Am. Geogr. 88: 183-208.

McLachlan, J.S., J.J. Hellmann and M.W. Schwartz. 2007. A framework for debate of assisted migration in an era of climate change. Conserv. Biol. 21: 297-302.

Millar, C.I., N.L. Stephenson and S.L. Stephens. 2007. Climate change and forests of the future: managing in the face of uncertainty. Ecol. Appl. 17: 2145-2151.
Pearson, R.G. and T.P. Dawson. 2003. Predicting the impacts of climate change on the distribution of species: are bioclimate envelope models useful? Global Ecol. Biogeo. 12: 361-371.

Pojar, J., K. Klinka and D.V. Meidinger. 1987. Biogeoclimatic Ecosystem Classification in British Columbia. For. Ecol. Manage. 22: 119-154.

Soja, A.J., N.M. Tchebakova, N.H.F. French, M.D. Flannigan, H.H. Shugart, B.J. Stocks, A.I. Sukhinin, E.I. Parfenova, F.S. Chapin III and P.W. Stackhouse Jr. 2007. Climate-induce boreal forest change: predictions versus current observations. Global Planet. Change 56: 274-296.

Stathers, J.P., R. Trowbridge, D.L. Spittlehouse, A. Macadam and J.P. Kimmins. 1990. Ecological principles; basic concepts. In: D.P. Lavender, R. Parish, C.M. Johnson, G. Montgomery, A. Vyse, R.A. Willis and D. Winston (eds.) Regenerating British Columbia's forests. UBC Press. Vancouver. pp 45-54.

Svenning, J.-C. and F. Skov. 2004. Limited filling of the potential range in European tree species. Ecol. Lett. 7: 565-573.

Thornton, P.E., S.W. Running and M.A. White. 1997. Generating surfaces of daily meteorological variables over large regions of complex terrain. J. Hydrol. 190: 214-251.

Thuiller, W. et al. 2008. Predicting global change impacts on plant species' distributions: Future challenges. Persp. Plant. Ecol. 9: 137-152.

Wilmking, M., G.P. Juday, V.A. Barbier and H.S.J. Zald. 2004. Recent climate warming forces contrasting growth responses of white spruce at treeline in Alaska through temperature thresholds. Global Change Biol. 10: 1-13.

Woodward, F.I. and D.J. Beerling. 1997. The dynamics of vegetation change: health warnings for equilibrium 'dodo' models. Global Ecol. Biogeo. Lett. 6: 413-418. 